\title{
PENGARUH REWARD DAN PUNISHMENT SEBAGAI SKEMA HASIL EVALUASI KINERJA KARYAWAN PADA PERUSAHAAN SWASTA
}

\author{
Rahmat Arfan ${ }^{1}$, Geta Ambartiasari ${ }^{2}$ \\ Politeknik Kutaraja ${ }^{1}$, Politeknik Indonesia Venezuela ${ }^{2}$ \\ (rahmatarfan@poltekkutaraja.ac.id)
}

\begin{abstract}
ABSTRAK
Isu yang menjadi pada penulisan ini adalah tentang hasil dari evaluasi yang dijalankan pada perusahaan, setelah menjadi perusahaan terbaik nasional selama dua tahun berturut-turut, menjadihal menarik untuk membahas bagaimana hasilevaluasi dijalankan pada reward dan punishment. Keinginan untuk mengetahui tentang bagaimana merangsang kinerja karyawan dengan dua metode ini patut dijalankan. Sehingga didapatkan bahwa pelaksanaan reward merupakan metode yang lebih baik di jalankan dibandingkan dengan punishment, namun reward dan punishmen patut dijalankan bersamaan namun punishment yang dijalankan didahulukan dengan peringatan yang bertahap, karena tujuan dari punishment dan reward adalah sama yaitu meningkatkan kinerja karyawan. Metode yang dijalankan pada jurnal ini dijalankans ecara destriptif kualitatif, dengan penggunaan subject dan object penelitian kepada karyawan pada jabatan sales eksekutif dengan didukung observasi dari data yang telah dikumpulkan.
\end{abstract}

Kata Kunci: Reward, Punishment, evaluasikinerja.

\begin{abstract}
The issue at this writing is about the results of the evaluation was run by a company after they to be the best company since last two years, it was interesting to discuss how evaluation result conducted on reward and punishment. The desire to know about how to stimulate employee performance with these two methods is worth executing. So it found the implementation of the reward is better to run than the punishment, but the reward and punishment should be run together. When running the punishment company need to give gradual warning to employee, because the purposes of reward and punishment are to increase employee performances. The research method used in this journal descriptive qualitative research with subject and object of this research is an employee at sales executive position and supported by observations from data collected.
\end{abstract}

Keywords: Reward, Punishment, Employee performance.

\section{A. PENDAHULUAN}

Dunia Bisnis terus berkembang dengan pesat yang mendorong persaingan ketat antar bidang. Hal ini mendorong perusahaan menghadapi permasalahan yang kompleks karena persaingan yang terjadi dari perusahaan lainnya dan internal perusahaan dari segi SDM karena perlunya pemenuhan target perusahaan, pelayanan yang maksimal serta pemenuhan kebutuhan konsumen secara penuh menunjukkan kualitas sebuah perusahaan. Barkaitan dengan pentingnya SDM sebagai penentu kualitas perusahaan baik sebagai tenaga kerja maupun member pelayanan maka perusahaan perlumenerapkan pengelolaan 
sumberdaya manusia yang tepat dengan salah satu metode yang diterapkan ialah reward and punishment.

Reward atau penghargaan diberikan kepada karyawan yang memiliki prestasi yang diharapkan akan memberikan motivasi kepada karyawan agar dapat terus mempertahankan dan meningkat kankinerja (Damayanti, Susilaningsih., \& Sumaryati, 2013). Reward juga dapat merangsang persaingan sehat antar karyawan dalam upaya pencapaian hasil kinerja yang baik. Kinerja yang terus membaik akan menciptakan produktivitas kerja yang meningkat, sehingga diharapkan dengan peningkatan ini akan juga meningkatkan laba perusahaan.

Punishment atau sanksi diberikan kepada karyawan yang tidak mencapai hasil kerja yang diharapkan dengan standar perusahaan seperti Key performance Index (KPI)(Remus, 2016), punishment adalah lawandari reward (Febrianti, 2014)yang diberikan kepada karyawan dengan harapan untuk menjadi peringatan kepada karyawan. Punishment tidak berarti hukuman atau sanksi yang negative karena sanksi yang diberikan merupakan bentuk peniliaian yang professional sehingga ini harusnya menjadi dampak positif disebabkan karyawan akan menghindar dari mendapatkan punishment.

Reward dan punishment merupahan poin penting dalam membentuk kinerja yang baik bagi karyawanan, hal ini berkaitan dengan kualitas dalam tugas serta bertanggungjawab dari hasil yang diberikan antara karyawan dan perusahaan. Setiap perusahaan yang menggunakan KPI sebagai standar peniliaian menggunakan reward dan punishment dalam outpun nilai takterkecuali pada perusahaan distribusi telekomunikasi. Persaingan yang terjadi antar provider telekomunikasi di Indonesia membentuk persaingan yang terbuka yang menuntut peningkatan secara enksternal dan juga internal perusahaan, salah satunyaialah PT. Tri BumiKutaja Area Aceh.

PT. Tri Bumi Kutaraja merupakan perusahaan yang bergerak pada bidang distribusi komunikasi yang orientasi kegiatan pada penjualan dalam bentuk kartu perdana dan voucher pulsa atau data, dalam kegiatan distribusi pelaksanaannya dilakukan dengan target baik harian, mingguan dan bulanan, setiap karyawan pada bidang sales dituntutun tuk melaksanakan penjualan secara aktif menurut area masing - masing dan mengembangkan pasar serta partner baru. Perusahaan ini terus mengalami 
pengembangan hal ini dapat dilihat selama dua tahun berturu-turut pada tahun 2018 dan 2019 masuk kedalam lima besar pencapaian terbaik secara nasional dari seluruh perusahaan distribusi yang berada di bawah naungan Hutchison three Indonesia, sebagaimana data pencapaian trade revenue yang terlampir:

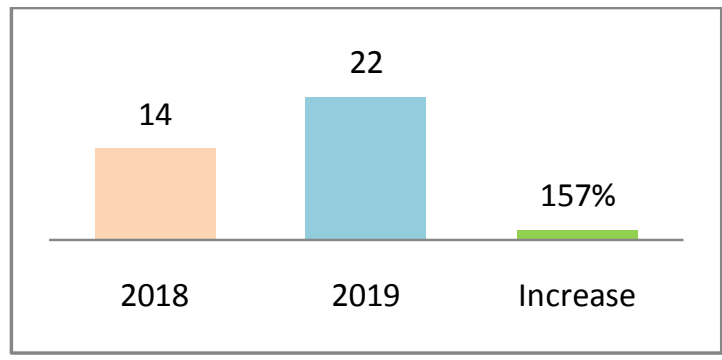

Ket: Trade revenue (satuandalammilyar)

\section{B. KAJIAN LITERATUR}

\section{a. Evaluasikinerja}

Evaluasi kinerja merupakan penilaian yang dilaksanakan perusahaan terhadap manajer dan karyawanannya dalam melaksanakan pekerjaannya (Wijayanti \& Wimbrati, 2012). Proses ini sangatlah penting dalam memotivasi karyawan terhadap pekerjaan mereka di tempat kerja. Dari hasil penilaian karyawan memerlukan feedback dari perusahaan terhadap evaluasi yang telah diberikan terhadap mereka baik dalam hasil yang bagus maupun tidak.

Jika hasil evaluasi yang telah dilaksanakan menghasilkan nilai yang kurang atau tidak memuaskan berdasarkans tandar yang telah ditetapkan, perusahaan perlu menyusun proses peningkatan kinerja bagi karyawan yang mendapatkan penilaian yang kurang baik tersebut.

Terdapat lima factor yang mempengaruhi peniliaian kinerja karyawan yaitu:

1. Prestasi karyawan, hal ini dilihat dari karyawan yang dapat menghasilkan hasil kerja dalam ketelitian, ketepatan dalam bekerja, dan keterampilan bekerja.

2. Kuantitas karyawan, dalam poin ini penilaian dilihat dari jumlah hasil kerja karyawan dengan tidak mengesampingkan hasil kerja karyawan serta banyaknya kontibusi yang diberikan oleh karywan terhadap perusahaannya.

3. Kepemimpinan yang diperlukan, proses panduan yang dibutuhkan oleh karyawan juga menjadi penilaian dari perusahaan, hal ini mengenai seberapa banyak karyawan perlu di pandu dan melihat kreatifitas karyawan dalam mengambil keputusan dan kegiatan pekerjaaan dalam mencapai hasil kerja.

4. Kedisiplinan, dalam factor ini kehadiran dan ketepatan waktu dalam menyelesaikan pekerjaaan menjadi penilai terhadap karyawan.

5. Komunikasi, pada factor ini cara berkomunikasi serta penerimaan karyawan terhadap karyawan lainnya dan 
terhadap pimpinannya menjadi peniliaian kinerja.(Dessler, 2009)

Penilaian kinerja merupakan proses evaluasi yang dilaksanakan oleh perusahaan terhadap karyawan mengenai level keberhasilan karyawan dalam menyelesaikan pekerjaan mereka dibandingkan dengan standar yang ditetepkan oleh perusahaan yang hasil tersebut kemudian di informasikan kepada karyawan dengan tujuan untuk meningkatkan hasil kerja mereka dan juga dalam memberikan reward atau punishment terhadap hasil dari kerja karyawan (Mathis \& John, 2001)

Keinginan dilaksanakan evaluasi kerja karyawan merupakan hal yang diinginkan oleh perusahaan dan karyawan. Dari sisi perusahaan penilaian dilaksanakan dengan tujuan untuk peningkatan hasil kerja dalam hal ini dapat meningkatkan keuntungan bagi perusahaan. Jika dilihat dari segi karyawan evaluasi kerja dapat menjadi dasar karyawan dalam mengembangkandiri, menerapkan target insentif dan dalam meningkatkan produktifikas kerja.

\section{b. Reward}

Reward atau penghargaan merupakan nilai yang diberikan oleh perusahaan dalam memberikan tanggapan terhadap upaya yang diberikan karyawan secara individu terhadap perusahaannya, system nilai yang dibangun merupakan hasil penilaian yang diberikan baik dalam bentuk financial ataupun nonfinancial (Retnowati, 2001). System nilai yang dibangun oleh perusahaan merupakan standar yang dibuat oleh perusahaan tersebut tekait dengan kontribusi karyawan, pengetahun dan kemampuan (Mahmudi, 2005).

Financial reward diberikan dalam bentuk pembayaran seperti kenaikan gaji, kenaikan tunjangan, mendapatkan bonus (Pamungkas, 2012). Pada non financial reward, penghargaan diberikan bukan dalam bentuk pembayaran namun dalam bentuk lainnya seperti kenaikan jabatan, kesempatan mengembangkan diri seperti sekolah kembali(Retnowati, 2001).

Reward dalam perusahaan dapat dibagi kepada dua point yaitu intrinsic dan ektrinsik (Triandani, 2017)

1. Penghargaan intrinsik

Reward inimerupakan upaya yang dilakukan di dalam diri pegawai itu sendiri yang diatur secara mandiri seperti perasaan puas terhadap penyelesaian ,pencapaian, otomi pertumbuhan pribadi.

2. Penghargaanekstrinsik

Reward ini merupakan haril kerja yang dilakukan oleh karyawan yang diberikan oleh perusahaan terhadap hasilkerja yang telah dilakukan oleh karyawan itu sendiri. Penghargaan ini dapat berbentuk seperti: 
a. Penghargaanfinansial,

Penghargaan financial dapat berbentuk kenaikan gaji, bonus atau insentif ataupun peningkatan tunjangan yang diterima oleh karyawan.

b. Jaminan social Selain jaminan financial jaminan haritua, jaminan keselamatan dan kesehatan dapat memberikan rasa kenyamanan karyawan dalam bekerja.

c. Bagi hasil keuntungan

Bagi hasil dari keuntungan mendorong karyawan untuk lebih giat dan semangat dalam bekerja dan menghasilkan kerja yang lebih baik. Bagi hasil keuntungan perusahaan dapat diberikan dari laba perusahaan ataupun saham perusahaan yang diberikan kepada karyawan yang berprestasi.

d. Penghargaanataupengakuan.

Factor non financial ini diberikan kepada karyawan sebagai bentuk penghargaan dalam mendorong psikologis karyawan dan terus bersemangat menghasilkan kerja yang baik.

e. Promosi atau kenaikan pangkat.

Kenaikan pangkat merupakan perpindahan karyawan kepada level atau jenjang posisi lebih tinggi dengan diberikepercayaan lebih dengan tanggungjawab yang meningkat.

f. Keanggotaan dalam kelompok informal.

Kepemimpinan yang diberikan pada kegiatan diluar organisasi formal, menjad ipendamping karyawan baru dan kesempatan untuk bergaul juga dapat memberikan nilai penghargaan kepada karyawan.

\section{c. Punishment}

Dalam pengertiannya punishment merupakan proses hukuman yang dilakukan oleh perusahaan terhadap hasil kerja dalam koridor SOP yang benar. Punishment merupakan hukuman yang diberikan dengan sengaja yang diberikan oleh seseorang akibat terjadi pelanggaran, atau kesalahan (Purwanto, 2006). Punishment merupakan hasil yang tidak diinginkan.

Terdapat bebera pajenis punishment yang diterapkan menurut tingkatannya (Bangun, 2012)

1. Hukuman ringan

Hukuman yang ditetapkan dalam level ini berfungsi sebagai peringatan yang berbentuk lisanmaupun tulisan yang di keluarkan oleh perusahaan, dalam tulisan terdapat beberapa tingkatan lagi 
yang pada umumnya disebut surat peringatan (SP) yang di awalai dengan $\mathrm{SPl}, \mathrm{SP} 2$.

2. Hukuman sedang

Hukuman sedang merupakan hukuman yang dilanjutkan setelah hukuman ringan dilaksanakan, pada level ini telah diberikan info terlebih dahulu pada surat peringatan, biasanya penundaan kenaikan gaji, pemotongan bonus atau tunjangan dan penundaan kenaikan pangkat.

3. Hukuman berat.

Merupakan hukuman level yang tertinggi pada proses punishment, dalam level ini penurunan pangkar, pembebasan dari jabatan dan pemutusan hubungan kerja antara perusahaan dan karyawan, atau pada peringatan diberikannya Surat peringatan ketiga.

\section{METODE PENELITIAN}

Metode penulisan yang dilaksanakan ialah secara desriptif hal ini bertujuan dalam memeroleh deskripsi bagaimana pelaksanaan reward dan punishment sebagai hasil dari evaluasi kinerja. Dalam pendekatan penelitian dilaksanakan secara kualitatif, hal ini agar memberikan asumsi penekanan dalam proses bukan pada hasil atau produk, dengan terlibatnya peneliti dilapangan sehingga interaksi terjadi dalam proses pengumpulan data di lapangan dengan proses melaksanakan catatan secara ilmiah(Creswell, 2007)

\section{a. Waktu dan lokasi}

Lokasi dilaksanakan di Aceh mencakup empat wilayah kotayaitu Banda Aceh, Sigli, lhoksumawe dan Langsa dengan jumlah karyawan keseluruhan ialah 39 karyawan dengan sampel yang di ambil adalah pada posisi lapangan atau Sales.

\begin{tabular}{lll}
\hline No & Posisi & Jumlah \\
\hline 1 & Commercial Manager & 1 \\
\hline 2 & Human resource & 1 \\
& Manager & \\
\hline 3 & Finance manager & 1 \\
\hline 4 & Territorial Manager & 4 \\
\hline 5 & Management & 1 \\
& Informatin System & \\
\hline 6 & Sales Executive & 18 \\
\hline 7 & Marketing Executive & 4 \\
\hline 8 & Admin Finance & 2 \\
\hline 9 & Admin Depo \& & 2 \\
& Logistic & \\
\hline 10 & Office Boy & 1
\end{tabular}

Ket: Posisi dan JumlahKaryawan

\section{b. Subjek dan objekpenelitian}

Subjek pada tulisan ini adalah karyawan pada perusahaan Swasta PT. Tri Bumi 
Kutaraja. Pada metode kualitatif subject dapat disebut juga sebagai informan yang dimanfaatkan dalam mendapatkan informasi bagi penelitian (Moleong, 2017). Adapun kriteria informan yang menjadi subject penelitian ialah karyawan pada perusahaan ini dan dalam jabatan sales eksekutif yang jujur dan bertanggungjawab terhadap kewajiban kerjanya.Pemilihan pada posisi sales disebabkan pada posisi ini mengalami turn over yang tinggi jika dibandingkan dengan jabatan lainnya.

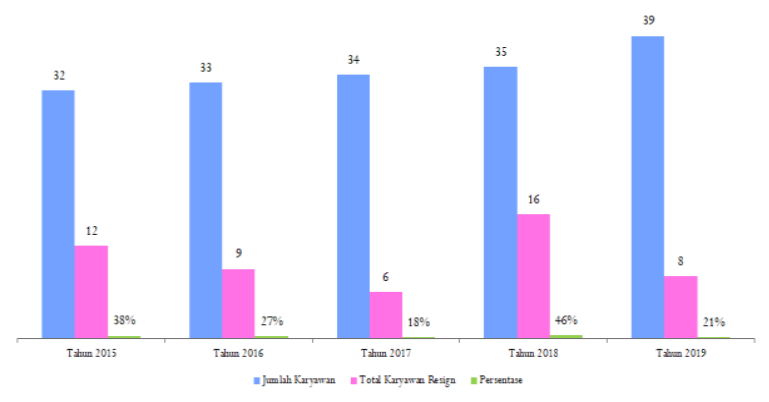

Ket: total turn over dan persentasedalam lima tahunterakhir

\section{c. Pengumpulan data}

Pengumpulan data dalam tulisan ini dilakukan dengan cara wawancara terstruktur dengan pertanyaan telah di tentukan oleh penulis guna focus tulisan di dapatkan dalam proses pengumpulan data. Pada pertanyaan wawancara di fokuskan kepada dua point yaitu reward dan punishment.
Obeservasi dari data juga dilakukan dengan pengumpulan dilaksanakan melalui hasil kinerja serta evaluasi yang dilakukan dalam penentuan terhadap reward dan punishment yang dijalan kepada karyawan. Data yang telah dikumpulkan dilihat dari data tahun 2018 sampai dengan 2019 dari bulan januari sampai dengan Desember .

Dokumenter atau kajian dokumen dilakukan guna mendapat laporan tertulis mencakup teori yang mendukung tulisan dan daftar informasi mengenai perusahaan tersebut.

\section{d. Analisa Data}

Analisa data yang dilakukan pada penelitian kualitatif ialah menggunakan tiga kegiatan yang dilaksanakan secara bersamaan ialah reduksi data, penyajian data, dan penarikan kesimpulan (Miles, 1994).

Pada reduksi kegiatan yang dilaksanakan ialah pemilihan, pemusatan perhatian dan transformasi dari data mentah dari lapangan. Proses ini ialah bertujuan untuk mengecilkan focus perhatian pada data, dan menggolongkan data serta menyaring data yang perlu dan tidak menggunakan data yang tidak berkaitan dengan data yang diperlukan. 
Dalam penyajian data dilakukan setelah reduksi dilakukan, data dikumpulkan dan disusun untuk yang kemungkinan untuk dapat diambil kesimpulan untuk diambil tindakan yang dituangkan dalam bentuk naratif, grafik, atau bagan.

Pada proses selanjutnya kesimpulan dan verifikasi merupakan analisa pada data yang telah melalui proses penyajian data ,hasil yang telah didapatkan akan dianalisa dengna prinsiplogika dan penelitian yang terdahulu dalam mengambil kesimpulan, proses ini akan terus berlangsung secara berulang terhadap data yang diperoleh.

\section{HASIL DAN ANALISIS PENULIS}

\section{a. Reward}

Reward atau penghargaan juga dijalankan pada perusahaan ini guna merangsang pencapaian bagi karyawan. Penghargaan yang diberikan umumnya bersifat ekstrinsik seperti:

1. Penghargaan finansial

Pada penghargaan financial yang dijalankan adalah insentif dan kenaikan gaji. Pada insentif penentuan nilai berdasarkan kepada target dan pencapaian setiap area dengan penentuan keberhasilan di akumulasikan dalam setiap bulannya.

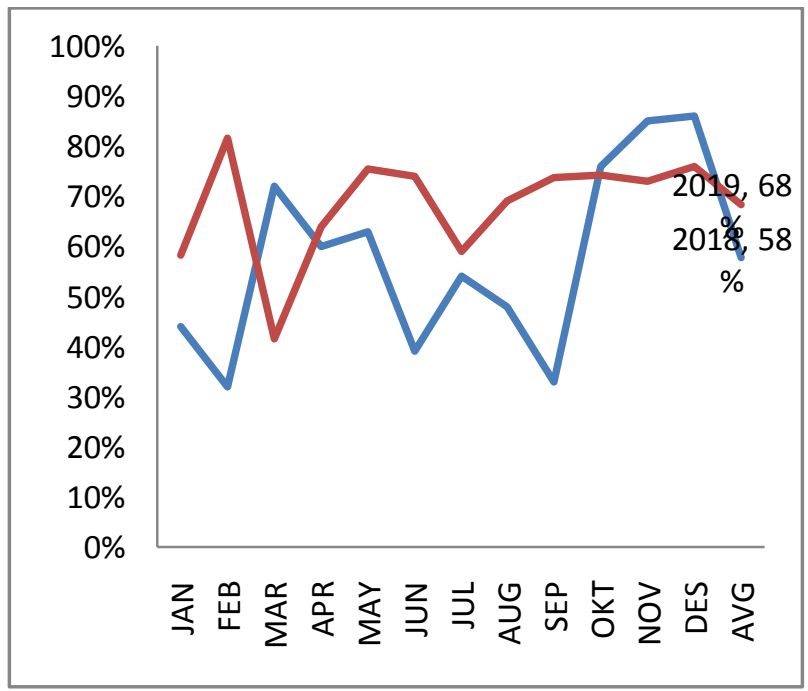

Incentive diberikan pada posisi sales yang ditentukan dari pencapaian KPI (Key Performance Incex) yang telah ditentukan pada awal tahun atau pada awal bulan. Berdasarkan gambar diatas, reward yang diberikan kepada karyawan mengalami proses nilai yang fluktuatif, terjadi perubahan dalam setiap bulannya, dan perbedaan pada tiap tahunnya, namun dari grafik di atas dapat dilihat rata-rata yang dicapai antara tahun 2018 dan 2019 mengalami peningkatan di mana pada tahun 2018 perolehan incentive ialah sebesar 58\% sedangkan pada tahun 2019 perolehan incentive ialah sebesar 68\%, terjadi kenaikan penyerapan incentive sebesar $10 \%$ dalam satu tahun. 
2. Penghargaanjaminan social

Penghargaan jaminan sosial pada perusahaan ini terdiri dari dua jaminan yaitu jamin BPJS kesehatan dan BPJS ketenagakerjaan. Sejauh ini pelaksanaanya merata seluruh karyawan, setiap karyawan mendapatkan hak yang sama karena merupakan kewajiban yang telah di tentukan oleh pemerintah

Pada BPJS kesehatan pembayaran di bagi kepada tanggungan karyawan sebesar 1\% dari gaji dan 4\% dari perusahaan, dan pada BPJS ketenagakerjaan kesemua paket perlindungan pekerja dijalankan seperti jaminan haritua, jaminan pensiun, jaminan kecelakaan kerja dan jaminan kematian tanggungan juga dibagi kepada dua pada perusahaan sebesar $6.24 \%$ dan pada karyawan sebesar 3\%, yang dasar perhitungannya berdasarkan gaji karyawan tersebut.

3. Promosi dan kenaikanjabatan

Promosi juga dijalankan pada karyawan yang berprestasi, pada penetapan promosi dilakukan dengan proses kemampuan dalam pencapaian KPI baik konsistensi dan pemahaman, senioritas, pendidikan, komunikasi dan dukungan seluruh tim menyebabkan seseorang dapat mendapatkan promosi.

Promosi yang dilaksankan ialan kenaikan pada jabatan Sales Eksekutif kepada Territorial Manajer, dan hasil yang didapatkan pada tahun 2018 dan 2019 hanya terjadi satu kali promosi pada setiaptahunnya.

\section{b. Punisment}

1. Hukuman ringan

Hukuman ringan diberikan dalam bentuk tulisan seperti surat peringatan yang dikeluarkan oleh manajemen kepada karyawan. Sebab pemberian surat peringatan ini karena terjadi pelanggaran yang perlu di tertibkan seperti masalah keuangan, kinerja yang menurun, kedisiplinan atau kehadiran yang menurun dan lainnya. Intensitas dikeluarkan SP yang diberikan dalam tahun 2018 dan 2019 dirangkum pada table berikut:

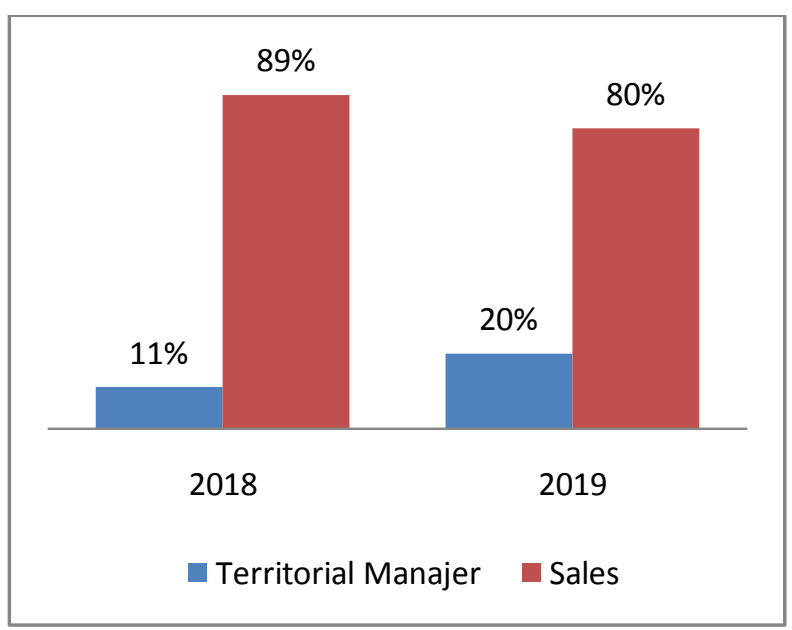


Ket: Persentasesuratperingatan yang dikeluarkan

Berdasarkan pada gambar di atas, pemberian surat peringatan terjadi peningkatan pada jabatan Territorial Manajerdari 11\% pada tahun 2018 menjadi 20\% pada tahun 2020. Namun pada jabatan sales terjadi penurunan dari $89 \%$ ada tahun 2018 menjadi 80\% pada tahun 2019.

2. Hukumanberat

Pada perusahaan ini tidak diterapkan hukuman sedang, biasanya proses punishment dijalankan dengan pemberian surat peringatan. Pada peringkat hukuman berat karyawan akan diberiperingatan terlebih dahulu dan pemutusan hubungan kerjasama. Hal ini dapat dilihat dari tingkat turn over yang terjadi dari tahun 2018 dan 2019 akibat dari punishment yang diterapkan oleh perusahaan.

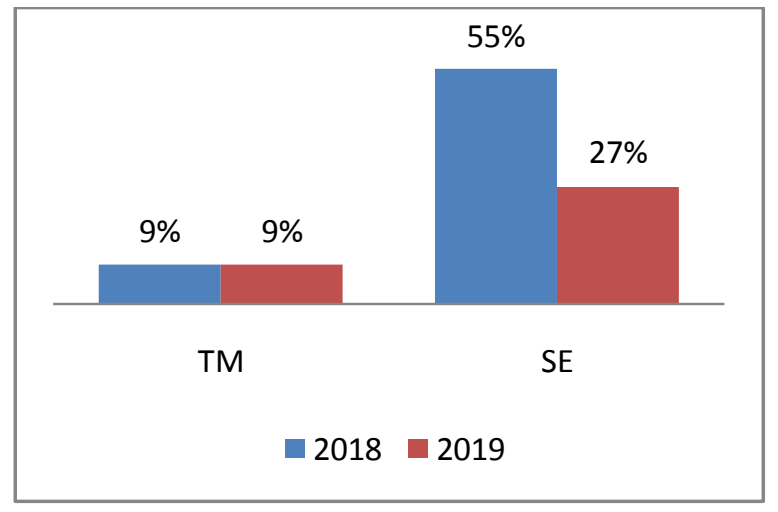

Ket: Persentase Turn over akibat punishment

Pada gambar dapat menjelaskan bahwa pada jabatan territorial manajer persentase antara 2018 dan 2019 adalah sama ialah sebesar 9\%, dan pada jabatan sales mengalami penurunan dari 55\% pada tahun 2018 menjadi 27\% pada tahun 2019 dengan total turn over akibat dari punishment ialah tujuh orang pada tahun 2018 dan empat orang pada tahun 2019.

\section{E. KESIMPULAN}

1. Konsep perusahaan swasta distribusi seperti pada PT. Tri Bumi Kutaraja dilaksanakan dengan sangat baik di mana perusahaan menerapkan konsep pertumbuhan atau growth, sehingga setiap bulannya target pertumbuhan akan naik. Konsep gwothini akan mempengaruhi target dari karyawannya dimana dituntun untuk melakukan pertumbuhan. Hal ini akan memberikan tekanan dalam kinerja karyawan dimana dituntut untuk terus berkembang baik dari segi individu dan secara kelompok.

2. Perkembangan karyawan juga menjadi perhatian perusahaan 
dimana memberikan reward dan punishment kepada karyawannya sehingga menjadi hasil dari evaluasi yang telah dijalankan oleh perusahaan. Perusahaan telah menjalankan konsep ini dan telah mengumumkant erlebih dahulu mengenai reward dan punishment yang tertuang dalam peraturan perusahaan. Dan pelaksanaan reward dan punishment juga sangat transparan dan bertahap.

3. Pada reward, bonus atau insentive diterapkan pada periode bulanan yang diberikan kepada karyawan pada setiap bulan gajian, dengan pencapaian KPI mereka di umumkan setiap bulannya, sehingga setiap karyawan akan mengetahui kekurangan individu masing masing yang diharapkan akan meningkatkan diri di periode selanjutnya.

4. Pada punishment penerapan peringatan tertulis juga telah dijalankan oleh perusahaan dengan melalui tahapan surat peringatan satu, dua dan tiga sebagai pemberitahuan adanya evaluasi teratur dalam punishment yang dijalankan.
5. Jika di bandingkan antara evaluasi kerja yang diterapkan dalam perusahaan, reward merupakan polahasil dari evaluasi kinerja yang cukup baik dalam pelaksanaannya. Hal ini dapat dilihat dari peningkatan yang cukup besar sebanyak 10\% di tahun 2019 jika di bandingkan pada tahun 2018. Pada punishment mengalami penurunan juga antara 2018 dan 2019, jika dilihat dari surat peringatan yang diberikan pada dua tahun tersebut terjadi penurunan sebesar 9\% di tahun 2019 jika dibandingkan dengan tahun 2018, diikuti dengan turn over yang juga terjadi penurunan sebesar $28 \%$ di tahun 2019.

6. Sehingga reward merupakan pola yang tepat dalam hasil dari hasil evaluasi kinerja karyawan dalam meningkatkan produktivitas karyawan pada sebuah perusahaan. Pola punishment yang bertahap dan procedural yang telah di himbaukan terlebih dahulu juga memberikan dampak yang positif sehingga turn over yang tidak diharapkan dapat diminimalisir. 


\section{Daftar Pustaka}

Bangun, W. (2012).

ManajemenSumberDayaManusia.

ManajemenSumberDayaManusia.

Creswell, J. W. (2007). Research Design: Qualitative, Quantitative and Mixed Method Aproaches. SAGE Publications. https://doi.org/10.4135/9781849208956

Damayanti, A. P., Susilaningsih., \&Sumaryati, S. (2013).

PengaruhKompensasi dan motivasikerjaterhadapkinerjakaryawan perusahaandaerah air minum (PDAM) surakarta. Jupe UNS, 2(1), 155-168.

Dessler, G. (2009). Personnel planning and recruiting. In A framework for human resource management.

Febrianti, S. (2014). Pengaruh reward dan punishment terhadapmotivasikerjasertadampaknya terhadapkinerja (studi pada karyawan PT. Panin Bank Tbk. Area MikroJombang). JurnalAdministrasiBisnis, 12(1). Retrieved from http://administrasibisnis.studentjourna l.ub.ac.id/index.php/jab/article/view/48 7

Mahmudi. (2005). Manajemen Kinerja SektorPublik. Yogyakarta: UPP AMP YKPN.

Mathis, R., \& John, J. (2001). ManajemenSumberDayaManusiaBuku 1. EdisiPertama, PenerbitSalembaEmpat, Jakarta.

Miles, M. A. (1994). Miles and Huberman (1994)- Chapter 4.pdf. In Qualitative Data Analysis: An Expanded Sourcebook.

Moleong, L. J. (2017).

MetodologiPenelitianKualitatif (EdisiRevisi). In PT. RemajaRosdaKarya.
Pamungkas, D. A. (2012). Hubungan

Reward dan Punishment dengantingkatmotivasikaryawandalam mematuhiperaturankeselamatan dan kesehatankerja. Junal Kesehatan Masyarakat, 1(2), 710-719. Retrieved from http://ejournalsl.undip.ac.id/index.php /jkm

Purwanto, N. (2006). Prinsip dan Teknik Evaluasi. Bandung: RemajaRosdaKarya.

Remus, S. P. (2016). analisis reward and punishment terhadapproduktivitaskerjakaryawan pada PT. Mina Jaya persadamakmurmedan. JurnalIlmiahMethonomi, 2(1). Retrieved from https://methonomi.net/index.php/jimet ho/article/view/9

Retnowati, E. (2001).

PersepsiTerhadapSistem Reward, KepuasanKerja dan MotivasiKerjaDosenmenurut Gender di Universitas Negeri Jakarta. Student Jurnal Universitas Indonesia.

Triandani, S. (2017). Pengaruh Organizational Citizenship Behavioral (OCB) Terhadap Kinerja Karyawan Pada PT. Inti KharismaMandiri Riau Pekanbaru. Jurnal Al-Iqtishad, 3, 27. Retrieved from http://ejournal.uinsuska.ac.id/index.php/aliqtishad/article/viewFile/3110/1987

Wijayanti, A., \&Wimbrati, S. (2012). evaluasi dan pengembangansistempenilaiankinerjap ata PT. HKS. JurnalPrsikologi, 1l(2), 14. https://doi.org/https://doi.org/10.14710/j pu.ll.2.14 